\title{
Використання комп'ютерної томографії в хірургічних хворих із туберкульозом легень
}

Калабуха І.А., Хмель О.В., Маєтний Є.М., Веремеєнко Р.А., Брянський М.В., Іващенко В.Є., Порк Є.М., Обремська О.К. ДУ «Національний інститут фтизіатрії і пульмонології ім. Ф.Г. Яновського НАМН України», м. Київ, Україна

Обґрунтування. Туберкульоз залишається поширеним захворюванням, і підвищення ефективності лікування хворих, особливо на хіміорезистентний туберкульоз, $є$ однією з важливих проблем охорони здоров'я. За період 20072018 рр. в Україні частота первинної хіміорезистентності становила від 7,0 до 20,0 \% у різних регіонах, а поширеність вторинної резистентності сягає від 60,0 до 75,0 \% на тлі недостатнього лікування нових випадків мультирезистентного туберкульозу легень (50,6-52,4 \%).

Мета. Визначення об'єктивних показань до оперативного втручання у хворих на туберкульоз на основі даних комп'ютерної томографії (КТ).

Матеріали та методи. Одним із наслідків лікування поширених форм туберкульозу $\epsilon$ утворення в легеневій тканині туберкуломи - форми специфічного процесу з торпідним перебігом, яка погано піддається інволюції під впливом антимікобактеріальної терапії. Ця форма туберкульозу навіть у разі стабільної клініко-рентгенологічної картини має високу ймовірність реактивації протягом перших 1-4 років із часу утворення. Туберкулома легень трапляється більш ніж у 10,0 \% випадків захворювання на туберкульоз. Проаналізовано патогістологічні висновки резекційного матеріалу 65 хворих (39 чоловіків, 26 жінок) віком від 24 до 60 років, оперованих із приводу туберкуломи легень із вимірюванням їхніх денситометричних показників на КТ органів грудної клітки.

Результати. Встановлено, що при середньому значенні щільності 54,4ะ17,8 одиниць Хаунсфільда (HU) та вище відзначається низька активність туберкульозного процесу, що відповідає фазі регресу захворювання. Значення щільності патологічно зміненої легеневої паренхіми в межах 27,6ะ7,5 HU відповідають помірній активності туберкульозного процесу, характеризуючи фазу стабілізації. Середні значення щільності 15,0 2,5 HU та нижче характеризують високу активність туберкульозного процесу та фазу прогресування захворювання.

Висновки. КТ $€$ об'єктивним неінвазивним методом дослідження, що дає змогу з високою достовірністю встановлювати ступінь активності специфічного запального процесу до оперативного втручання. Дослідження середнього, мінімального та максимального значення показника щільності на фіксованій площі осьового зрізу на КТ фактично відображає гістологічну структуру осередку й допомагає виявляти в ньому ділянки з високою активністю специфічного запального процесу. 